\title{
Czytanie jako (prze)grywanie
}

Czytanie jest tęsknotą za dialogiem, wielogłosowością, odbiorem sceny pisma, kontaktem $\mathrm{z}$ drugą osobą, odmiennym istnieniem, innym tekstem, tajemnicą, transcendencją. Lektura otwiera paradoksalną przestrzeń wielogłosu ciszy i milczenia. Czytanie buduje dramaturgię sceny, ogarnia pustkę niezapełnionej kartki, natłok znaków i zapisków na glosie, przypadkowy (konieczny?) rysunek na marginesie, zakomponowany obszar strony. Między wygłosem roli a gwarem antraktu stwarza interakcję z widzami, „wpuszcza” w pole pomiędzy tekstem a aktorem gest, oddech, spojrzenie. Byt tekstu stając naprzeciw osoby, sprawia, że w procesie lektury litera i postać wtapiają się w siebie. Akt takiego czytania jest aktem oddania siebie tekstowi i tekstu sobie.

Wraca dziś nieoczekiwanie idea głośnego czytania zarówno tego dla dzieci (bez nagrań, własnym głosem, bez znajomości rygorów dykcji aktorskiej, bez retorycznej celebry, ale umożliwiającego kontakt z ciałem przytulenie, objęcie, złapanie za rękę, gest otwarcia i zamykania księgi), jak i tego publicznego, choćby coraz częstszych teatralnych tzw. „prób czytanych" (które sprawiają, że widz dopuszczony „na próbę” do teatru pozbawionego magii scenicznych oddziaływań scenografii, kostiumu, muzyki zaczyna słyszeć głos i rozumieć tekst. Otoczony materią słowa, jego brzmieniem, pięknem i brzydotą, na przemian odkrywa magię teatru tam, gdzie już jej istnienia nie podejrzewał, tam, gdzie trwa ona odarta ze sztuczności, pozbawiona wszystkich "efektów specjalnych”. Takie czytanie odsłania dramaturgię tekstu wraz z budowaniem dramaturgii własnej interpretacji. Taka „próba czytana" czyni tekst moim, on przylega do mnie, okazuje się (zgodnie z Przybosiowską metaforą) ruchem, który „opina mnie - pancerz”. Ruch czytania chroni, opina jak pancerz, ale też jego obecność owija niczym słynna Norwidowska nić, „ta nić czarna się przędzie. Ona ze mną, przede mną i przy mnie". Czytanie jest wtedy tajemnicą doznania jednostkowego, doświadczenia dotyku słowa, wyrażenia niemego gestu, utrwalenia niepochwytnego bytu.

Teatralizacji w pisaniu odpowiada doświadczenie dramatyczne, które z dramaturgii lektury czyni dramaturgię poznania.

Czytanie jest nie tylko (od)grywaniem cudzego tekstu, ale też stałym (prze)grywaniem - przegrywaniem jego/przegrywaniem z nim.

W procesie czytania dokonujemy rodzaju przegrywania taśmy (jak to czyni Krapp w sztuce Becketta) i równocześnie stajemy wobec przegrywania z możliwością ostatecznego zrozumienia (znów w taki sposób, jak przegrywał walkę z czasem i tekstem Krapp). Czytanie jako przegrywa- 
nie jest powieleniem, w którym (przywołując pogłos myśli Arystotelesa) przegrany jest bogatszy od wygranego. Lecz sądzić też można, że nie istnieje wygrany jako zwycięzca nad tekstem. Tekst można rozegrać wygrać z nim nie sposób. To właśnie jest dramatyczną siłą artystycznego poznania - prawdy powtórzenia, jako powrotu od lektury do pisania; stałego rytmu - tam i z powrotem. Między (prze)grywaniem jako powtórzeniem a (prze)graniem jako porażką dokonuje się proces doświadczenia estetycznego.

W skrajnym przypadku odczytywanie może okazać się równoznaczne $\mathrm{z}$ dosłownym przepisywaniem tekstu, rozumienie dzieła staje się tożsame $\mathrm{z}$ aktem prze-pisywania, jednoznacznym $\mathrm{z}$ drogą wiodącą przez pismo. Przepisywanie utworu dawnego jest rodzajem adaptacji scenicznej tworzącej akt własnej opowieści danej słowami minionego tekstu. Przepisać oznacza napisać raz jeszcze. Zapis na taśmie Krappa z pozoru tylko i jedynie we fragmentach ma linearny przebieg. Naprawdę rozpada się na fragmenty naszej niespójnej pamięci stale oglądanej jako różne głosy o nas samych (głosy innych realizujące się w mowie własnej, traktowanej jako odmienna, zewnętrzna, nietożsama $\mathrm{z}$ nami). Tekst okazuje się moim - jak pamięć Krappa, która jest jego tylko poprzez dystans wobec swojej opowieści. Pamięć jest zbiorem własnych narracji uznanych za obce. Czytając je, paradoksalnie, odnajdujemy siebie. Przegrywając taśmę, powtarzamy, przepisujemy tekst wraz z jego technicznymi niedoskonałościami, niszczenie zapisu przez czas jest naszą porażką, ale i otwarciem nowych obszarów pamięci.

Czytając teksty, czytamy świat, i odwrotnie - poprzez doznanie świata budujemy teksty. Ciało tekstu i nasze ciało doświadcza zdarzeń czytania po to, by zmierzyć się kolejny raz z próbami podjęcia pytania o byt, stale wyrażać zdziwienie paradoksami egzystencji i sztuki, sztuki i egzystencji.

Anna Krajewska 